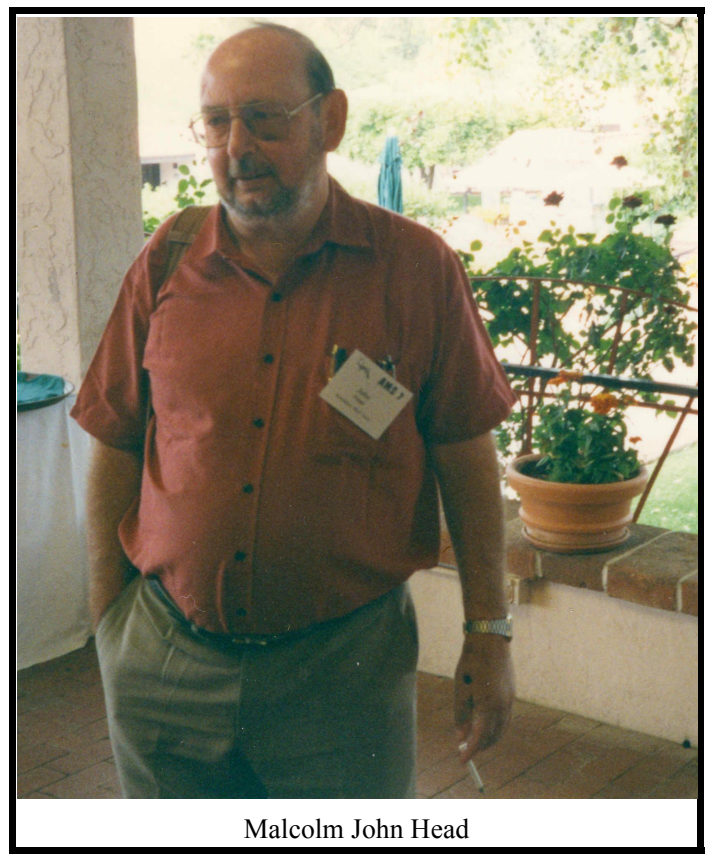

\title{
DR. JOHN HEAD IS VERY NEAR TO US
}

We suddenly heard the sad news that John Head had passed away, which made all of us in our institute deeply grief-stricken. We cannot believe it is true because I had just phoned him three days earlier. He told me that he had been well, except for high blood pressure. He was going to Xi'an, China with me after the 2003 Radiocarbon Conference.

The death of John means I have lost a good teacher and a helpful friend. It is even more of a great loss, not only for the State Key Laboratory of Loess and Quaternary Geology of China, but also for the whole radiocarbon community. He had cooperated with us for 19 years. His every word and action often appears before me and stays in my mind. It was in 1984 when I first met him in Guiyang. He gave a report about the chemical pretreatment of bone fossils and demonstrated it himself in the laboratory. Though he looked a little shy, he worked very carefully and hard. I knew at that time that he came from a well-known university in the Southern Hemisphere and he had been a radiocarbon expert with much practical experience over 20 years. However, I was a student at that time; I thought he was very far from me...

Actually, John is very near to us. When I first went abroad after the opening of China, I collaborated with the Australian National University in 1987 on the Loess chronology. John himself went to the Sydney airport to meet me, and then flew with me back to Canberra. I was deeply moved by this and have never forgotten, since he could have easily have just met me at Canberra airport. As soon as he met me at the Sydney airport, he excitedly told me that his laboratory had been successful in dating small samples with 100-200 mg carbon using a Quantulus counter and he suggested that it was necessary for Xi'an to build a method to date small samples using a liquid scintillation counter.

With the help of John, the method of small sample preparation for liquid scintillation counting was systematically built in our laboratory. This method was important in solving difficulties of small 
sample dating in geology and archaeology, particularly as there was no AMS radiocarbon facility in those days.

The cooperation with John benefited us a great deal. It was he who introduced for the first time to Chinese scientists that the key to the reliability of ${ }^{14} \mathrm{C}$ dating depends on the physical and chemical pretreatment of samples. It was he who helped our laboratory to set up chemical methods of pretreatment for different samples. The methods included organic separation from paleosol, the separation of primary and secondary carbonate, and the extraction of wood cellulose and bone collagen. This was a great step forward in ${ }^{14} \mathrm{C}$ dating in China.

In recent years, John joined us in studying the characteristics of the Younger Dryas in monsoonal China and its spatial variations. We proposed that the Younger Dryas precipitation fluctuation was contributed to not only by the summer monsoon, but also by paleo ENSO. This gave a picture of the Younger Dryas pattern from high latitude to middle-low latitude areas, and provides a historic analogue for future prediction. This scientific work will always remind us of John.

He also made an important contribution to our laboratory in the education of the younger generation. All of our students graduated with degrees in geology and experimental laboratory work was their common weakpoint. He tirelessly, conscientiously, and meticulously taught them himself, step by step, until they learned and did well. He still spent a lot of spare time in helping Chinese scientists both in and out of our laboratory to revise their English manuscripts, including scientists such as Prof Chen Jun (Vice President of Nanjing University), Prof Peng Zhicheng (China University of Science and Technology, Chinese Academy of Sciences), and many others.

We remember not just a geochemist but a generous and kind personality and an unselfish scientist. Though a lot of frustrations and difficulties filled his life, he leaves a free, easy, and high-spirited figure for us to remember.

As an experienced expert in radiocarbon dating, he left our young people innovative scientific ideas, strict experimental protocols, and an enthusiasm to continue in the field.

John lives in our hearts forever. Let us turn the grief into strength and make more scientific contributions for the good of all mankind.

\section{Weijian Zhou}

\section{SELECTED PUBLICATIONS}

Fifleld LK, Allay GL, Ophel TR, Head MJ. 1992. Accelerator mass spectrometry of ${ }^{14} \mathrm{C}$ at the Australian National University. Radiocarbon 34(3):452-7.

Head MJ, Taylor LJ, Walker D. 1994. ANU radiocarbon date list XI: radiocarbon dates from lakes Barrine and Eacham, Atherton Tableland, North Queensland, Australia. Radiocarbon 36(1):73-94.

Head MJ, Zhou W, Zhou M. 1989. Evaluation of ${ }^{14} \mathrm{C}$ ages of organic fractions of paleosols from Loess-paleosol sequences near Xian, China. Radiocarbon 31(3):680 96.

Hoper ST, McCormac FG, Hogg AG, Higham TFG, Head MJ. 1998. Evaluation of wood pretreatments on oak and cedar. Radiocarbon 40(1):45-50.
Polach HA, Rhodes EG, Head J, Gower J. 1982. ANU date list IX. Radiocarbon 24(1):36-44.

Tuniz C, Fink D, Hotchkis M, Jacobsen G, Lawson E, Smith A, Hua Q, Drewer P, Lee P, Levchenko V, Bird R, Boldeman J, Barbetti M, Taylor G, Head J. 1995. The Antares AMS Centre: a status report. Radiocarbon 37(2):663-74.

Zhou W, Zhengkun W, Jull AJT, Burr G, Donahue DD, Baosheng L, Head J. 2001. Environmental and climatic change as recorded in geological sediments from the arid to semi-arid zone of China. Radiocarbon 43(2B):619-27.

Zhou W, Head MJ, Wang F, Donahue DJ, Jull AJT. 1999. The reliability of AMS radiocarbon dating of shells 
from China. 1999. Radiocarbon 41(1):17-24.

Zhou W, An Z, Jull AJT, Donahue DJ, Head MJ. 1998. Reappraisal of Chinese Loess Plateau stratigraphic sequences over the last 30,000 years: precursors of an important Holocene monsoon climatic event. Radiocarbon 40(2):905-13.

Zhou W, An Z, Head MJ. 1994. Stratigraphic division of Holocene Loess in China. Radiocarbon 36(1):37-45.
Zhou W, Head MJ, Kaihola L. 1994. Small sample dating in China. Radiocarbon 36(1):47-9.

Zhou W, An Z, Lin B, Mao J, Zhang J, Xie J, Zhou M, Porter SC, Head MJ, Donahue DJ. 1992. Chronology of the Baxie Loess profile and the history of monsoon climates in China between 17,000 and 6000 years BP. Radiocarbon 34(3):818-25. 